\title{
Methanolic extract of Origanum vulgare ameliorates type 1 diabetes through antioxidant, anti-inflammatory and anti-apoptotic activity
}

\author{
Milica Vujicic ${ }^{1}$, Ivana Nikolic ${ }^{1}$, Vassiliki G. Kontogianni ${ }^{2}$, Tamara Saksida ${ }^{1}$, Pantelis Charisiadis ${ }^{2}$, \\ Zorana Orescanin-Dusic ${ }^{3}$, Dusko Blagojevic ${ }^{3}$, Stanislava Stosic-Grujicic ${ }^{1}$, Andreas G. Tzakos ${ }^{2 *}$ \\ and Ivana Stojanovic ${ }^{1 *}$ \\ ${ }^{1}$ Department of Immunology, Institute for Biological Research "Sinisa Stankovic", University of Belgrade, \\ Bulevar despota Stefana 142, 11060 Belgrade, Serbia \\ ${ }^{2}$ Department of Chemistry, Section of Organic Chemistry and Biochemistry, University of Ioannina, \\ GR-45110 Ioannina, Greece \\ ${ }^{3}$ Department of Physiology, Institute for Biological Research "Sinisa Stankovic", University of Belgrade, \\ 11060 Belgrade, Serbia
}

(Submitted 20 May 2014 - Final revision received 23 October 2014 - Accepted 10 November 2014 - First published online 11 February 2015)

\begin{abstract}
Type 1 diabetes (T1D), an autoimmune inflammatory disorder, develops as a consequence of pancreatic $\beta$-cell destruction and results in hyperglycaemia. Since current T1D therapy mainly involves insulin replacement, the aim of the present study was to evaluate the therapeutic potential of Origanum vulgare L. ssp. hirtum (Greek oregano) leaf extract rich in biophenols for the treatment of T1D. The phytochemical profile of methanolic oregano extract (MOE) and aqueous oregano extract (AOE) was determined by liquid chromatography/electrospray ion-trap tandem MS (LC/DAD/ESI-MSn), while their main compounds were quantified by HPLC with diode array detection. After establishing their potent in vitro antioxidant activity, the extracts were administered to C57BL/6 mice treated with multiple low doses of streptozotocin for diabetes induction. While prophylactic AOE therapy had no impact on diabetes induction, MOE reduced diabetes incidence and preserved normal insulin secretion. In addition, MOE scavenged reactive oxygen and nitrogen species and, therefore, alleviated the need for the up-regulation of antioxidant enzymes. MOE treatment specifically attenuated the pro-inflammatory response mediated by $\mathrm{T}$ helper 17 cells and enhanced anti-inflammatory $\mathrm{T}$ helper 2 and T regulatory cells through the impact on specific signalling pathways and transcription factors. Importantly, MOE preserved $\beta$-cells from in vitro apoptosis via blockade of caspase 3. Finally, rosmarinic acid, a predominant compound in MOE, exhibited only partial protection from diabetes induction. In conclusion, acting as an antioxidant, immunomodulator and in an anti-apoptotic manner, MOE protected mice from diabetes development. Seemingly, there is more than one compound responsible for the beneficial effect of MOE.
\end{abstract}

Key words: Type 1 diabetes: Oregano: $\mathbf{I L}-17$ : T helper 2 cells: T regulatory cells

Type 1 diabetes (T1D) is a chronic autoimmune disease typically characterised by the progressive destruction of insulin-producing $\beta$-cells in the islets of Langerhans within the pancreas that leads to the loss of glucose homeostasis ${ }^{(1)}$. T1D is diagnosed when $\beta$-cells are almost completely destroyed, and patients need insulin replacement therapy in order to survive. T1D is initiated as a consequence of a collapse in immune regulation, i.e. infiltration of pathogenic macrophages and dendritic cells into pancreatic islets is followed by the recruitment of autoreactive $\mathrm{CD}^{+}$and $\mathrm{CD}^{+} \mathrm{T}$ lymphocytes ${ }^{(2)}$
Since $\beta$-cells possess very low antioxidant protection, they easily succumb to the detrimental effect of macrophage-derived cytokines, reactive oxygen species (ROS) and reactive nitrogen species (RNS) or to the action of $\mathrm{T}$ cell-secreted pro-inflammatory cytokines such as interferon- $\gamma$ (IFN- $\gamma$ ) and IL-17 ${ }^{(3-6)}$. Furthermore, during T1D initiation, there is a breach in $\mathrm{T}$ helper (Th) 2 and regulatory $\mathrm{T}$ cell $\left(\mathrm{T}_{\mathrm{reg}}\right)$ responses and overall inability to control the development of autoimmunity ${ }^{(7,8)}$.

Despite the growing knowledge about T1D aetiology, therapies that can change the course of immune-mediated

Abbreviations: AOE, aqueous oregano extract; DPPH, 2,2-diphenyl-1-picrylhydrazyl; GSHPx, glutathione peroxidase; IFN- $\gamma$, interferon- $\gamma$; MLDS, multiple low doses of streptozotocin; MOE, methanolic oregano extract; PC, peritoneal cells; PLNC, pancreatic lymph node cells; RNS, reactive nitrogen species; ROR $\gamma t$, RAR-related orphan receptor $\gamma t$; ROS, reactive oxygen species; SOD, superoxide dismutase; STAT3, signal transducer and activator of transcription 3; STZ, streptozotocin; T1D, type 1 diabetes; TGF- $\beta$, transforming growth factor- $\beta$; Th, T helper; $\mathrm{T}_{\text {reg, }}$, regulatory T cells.

*Corresponding authors: A. G. Tzakos, email agtzakos@gmail.com; I. Stojanovic, fax +381 112761433 , email ivana@ibiss.bg.ac.rs 
destruction and preserve or even regenerate pancreatic $\beta$-cells seem to be promising in pre-clinical trials, but, unfortunately, so far, they are unsuccessful in human studies. This provides the need for the development of new therapeutic strategies. One of the potential approaches would be exploring traditional phytotherapies as alternative and/or supplementary therapy for diabetes treatment. Extensive studies have linked the consumption of food and natural products of plant origin rich in biophenols with protection against chronic diseases ${ }^{(9)}$. Origanum vulgare L. ssp. hirtum (Greek oregano) is a native plant rich in phenolic and ester compounds, especially in rosmarinic acid ${ }^{(10)}$. This plant has been used as an antiseptic and for stomach and respiratory ailments ${ }^{(11)}$. Also, it was tested for the treatment of non-immune 'toxic' diabetes induced by a high dose of streptozotocin $(\mathrm{STZ})^{(12)}$. The main medicinal activities of oregano are anti-bacterial ${ }^{(13)}$, antioxidant $^{(14)}$ and antithrombotic ${ }^{(15)}$ activities.

Since oxidative stress is one of the contributors to T1D development, the goal of the present study was to evaluate the effect of oregano leaf extracts on diabetes induction in the multiple low doses of STZ (MLDS) model of diabetes in C57BL/6 mice, and to determine the mode of action by testing the plausible antioxidant, immunomodulatory and cytoprotective effects.

\section{Experimental methods \\ Plant material, reagents and standards}

O. vulgare L. ssp. hirtum (Greek oregano) was a commercial sample (voucher accession no. UOI100912, University of Ioannina obtained from a biological cultivator (Maria Komini) from the region of Epirus, northwestern Greece (biological cultivation)). All solvents were of appropriate purity and were purchased from various suppliers. Formic acid was of analytical grade from Merck. Folin-Ciocalteu phenol reagent was obtained from Fluka, 2,2-diphenyl-1-picrylhydrazyl (DPPH) (approximately 90\%), carvacrol (98\%) and naringenin (95\%) were from Sigma-Aldrich. Rosmarinic acid (95\%) and eriodictyol (95\%) were from Fluka.

\section{Sample preparation}

The dried plant material was pulverised into a fine powder. In order to prepare methanolic oregano extract (MOE) for preliminary experiments, ground oregano leaves $(5 \mathrm{~g}$ ) were extracted sequentially with $200 \mathrm{ml}$ of four solvents of gradually increasing polarity in a Soxhlet apparatus for $6 \mathrm{~h}$ with each solvent, except for methanol $(12 \mathrm{~h})$. The sequence of the solvents was as follows: hexane (to remove chlorophylls); ethyl acetate; dichloromethane; methanol. MOE was concentrated using a rotary evaporator and kept in sealed dark flasks after a few minutes of $\mathrm{N}_{2}$ flushing. For all the other experiments, MOE was prepared from $32.7 \mathrm{~g}$ of plant material that were placed in a different Soxhlet apparatus and were extracted with $200 \mathrm{ml}$ of organic solvents, and then the extracts were combined. For preliminary experiments with aqueous oregano extract (AOE), ground oregano leaves $(5 \mathrm{~g})$ were placed in $100 \mathrm{ml}$ of boiling distilled water, kept in it for $1 \mathrm{~h}$ (out of fire) and then filtered. Water was removed with a freeze-dryer. For all the subsequent experiments, $15 \cdot 0 \mathrm{~g}$ of plant material were extracted with $300 \mathrm{ml}$ of distilled water and combined together. The yield of MOE was $15 \%$ and of AOE $9 \%$.

\section{Liquid chromotography-MS analysis}

All liquid chromotography-MS ${ }^{n}$ experiments were performed on a quadruple ion-trap mass analyser (model MSD trap SL; Agilent Technologies) retrofitted to a 1100 binary HPLC system equipped with a degasser, autosampler, diode array detector and electrospray ionisation source (Agilent Technologies). All hardware components were controlled by Agilent Chemstation Software.

AOE was dissolved in $\mathrm{H}_{2} \mathrm{O}-\mathrm{MeCN}(50-50 \%, \mathrm{v} / \mathrm{v})$ to the desired concentration of $1 \mathrm{mg}$ of dry extract $/ \mathrm{ml}$, and MOE was dissolved in methanol to the same concentration. A $10 \mu$ l aliquot was filtered $(0.45 \mu \mathrm{m})$ and injected into the liquid chromotography-MS instrument. Separation was achieved on a $25 \mathrm{~cm} \times 4.6 \mathrm{~mm}$ inner diameter, $5 \mu \mathrm{m}$ Zorbax Eclipse XDB-C18 analytical column (Agilent Technologies), at a flow rate of $0.6 \mathrm{ml} / \mathrm{min}$, using solvent A (water-formic acid, 99.9:0.1, v/v) and solvent $\mathrm{B}$ (acetonitrile). The gradient used for the analysis of oregano extracts was: $0-25 \mathrm{~min}, 90-30 \% \mathrm{~A} ; 25-29 \mathrm{~min}$, $30 \% \mathrm{~A} ; 29-30 \mathrm{~min}, 30-0 \% \mathrm{~A} ; 30-35 \mathrm{~min}, 0-90 \% \mathrm{~A}$. UV-vis spectra were recorded in the range of $200-400 \mathrm{~nm}$, and chromatograms were acquired at 254, 280 and $330 \mathrm{~nm}$.

Both precursor and product $\left(\mathrm{MS}^{2}\right.$ and $\mathrm{MS}^{3}$ ) ions scanning of the phenolic compounds were monitored between $\mathrm{m} / z 50$ and $m / z 1.000$ in negative polarity. The ionisation source conditions were as follows: capillary voltage, $3.5 \mathrm{kV}$; drying gas temperature, $350^{\circ} \mathrm{C} ; \mathrm{N}_{2}$ flow and pressure, 11 litres/min and 50 psi, respectively. The maximum accumulation time of the ion trap and the number of MS repetitions to obtain the MS average spectra were set at 30 and $3 \mathrm{~ms}$, respectively.

\section{Determination of the total phenolic content}

The total phenolic content of the extracts was measured using the Folin-Ciocalteu method described in detail in our previous work $^{(16)}$. All measurements were performed in duplicate.

\section{Antioxidant activity: 2,2-diphenyl-1-picrylhydrazyl radical-scavenging assay}

The DPPH radical-scavenging effect was evaluated according to the method described previously ${ }^{(16)}$. Results are presented as the values of scavenging concentration $50 \%\left(\mathrm{SC}_{50}\right) . \mathrm{SC}_{50}$ is the concentration of the extract that is sufficient to obtain $50 \%$ of a maximum scavenging capacity of the stable DPPH radical. Thus, the $\mathrm{SC}_{50}$ value is negatively related to antioxidant activity.

\section{Multiple low-dose streptozotocin-induced diabetes}

C57BL/6 mice were bred and kept in the animal facility at the Institute for Biological Research 'Sinisa Stankovic' (University of Belgrade, Belgrade, Serbia). Both institutional and national guidelines for the care and use of animals were followed, and 
all experimental procedures involving animals were approved by the Ethics Committee at the Institute for Biological Research 'Sinisa Stankovic', University of Belgrade, Belgrade, Serbia (approval number 2-27/10-01-189) in compliance with the Directive 2010/63/EU.

In order to investigate the efficacy of the extracts and rosmarinic acid in the treatment of diabetes, a mouse model of diabetes that closely resembles inflammatory changes within the pancreas in humans was used. Diabetes was induced in 8- to 12 -week-old male C57BL/6 mice with MLDS $(40 \mathrm{mg} / \mathrm{kg}$ per d, intraperitoneally for five consecutive days; SigmaAldrich). Each experimental group comprised ten animals. MOE or AOE was administered for ten consecutive days by intraperitoneal injections at a dose of $5 \mathrm{mg} / \mathrm{kg}$ per $\mathrm{d}$, starting from the day of MLDS induction ('prophylactic' regimen) or starting $1 \mathrm{~d}$ after the last STZ injection ('early therapeutic'). Rosmarinic acid was administered intraperitoneally for ten consecutive days $(2.5 \mathrm{mg} / \mathrm{kg}$ per $\mathrm{d})$, starting from the day of diabetes induction. Glucose concentration was measured from the blood drawn from the tail vein using a glucometer (Sensimac; IMACO GmbH). Clinical diabetes was defined by hyperglycaemia in non-fasted animals (blood glucose $>11 \mathrm{~mm}$ ). MOE was also administered to healthy mice for $10 \mathrm{~d}$, and general metabolic and immune parameters, and antioxidant enzymes were evaluated $14 \mathrm{~d}$ from the beginning of the experiment. The control mice received the vehicle $($ PBS + dimethyl sulfoxide (DMSO)).

\section{Metabolic parameters and leucocyte and erythrocyte blood counts}

Urine was tested for the presence of proteins, glucose and blood by using semi-quantitative Bayer Multistix ${ }^{\circledR} 10$ SG Urine Test Strips (Bayer). Blood was diluted in Türk's solution (Sigma-Aldrich) and leucocytes were counted in the haemocytometer, while blood was diluted in saline for counting erythrocytes. Glutathione $S$-transferase (as a measure of liver toxicity) was determined by enzymatic reaction. Briefly, glutathione $S$-transferase catalyses the reaction of 1-chloro-2,4-dinitro benzene with the glutathione sulfhydryl group. Newly created 1-chloro-2,4-dinitro benzene-S-glutathione has maximum absorption at $340 \mathrm{~nm}$ that was detected using a Shimadzu UV-160 spectrophotometer (Shimadzu Scientific Instruments, Shimadzu Corporation).

\section{Assessment of insulin}

Insulin concentration in the sera of non-fasted mice was determined using an ELISA kit (Mercodia).

\section{Cell preparation and culture}

Ex vivo analysis was performed on MLDS-induced C57BL/6 mice after 'prophylactic' administration of MOE on day 10 of post-diabetes induction. In vitro analysis was performed on cells isolated from male C57BL/6 mice. Mice were killed by cervical dislocation. To obtain spleen cells (SC) and pancreatic lymph node cells (PLNC), organs were mechanically disrupted by gentle teasing through the cell strainer (BD Bioscience), and cells were collected by centrifugation. Peritoneal cells (PC) were collected from the peritoneal cavity of mice in cold PBS. Erythrocytes were lysed using lysis buffer (eBioscience). Samples of conditioned medium, used for ex vivo detection of cytokines or $\mathrm{NO}$, were obtained by seeding the cells $\left(5 \times 10^{6} \mathrm{SC} / \mathrm{ml}\right.$ per well, $3 \times 10^{6} \mathrm{PLNC} / \mathrm{ml}$ per well, or $1 \times 10^{6} \mathrm{PC} / \mathrm{ml}$ per well) for $48 \mathrm{~h}$ in twenty-fourwell culture plates (Sarstedt) in Roswell Park Memorial Institute-1640 medium (with $25 \mathrm{~mm}$-HEPES and $2 \mathrm{~mm}-\mathrm{L}-$ glutamine) supplemented with $5 \%(\mathrm{v} / \mathrm{v})$ fetal calf serum (PAA Chemicals), penicillin/streptomycin (Sigma-Aldrich), and $5 \mu \mathrm{m}-\beta$-mercaptoethanol (Sigma-Aldrich) at $37^{\circ} \mathrm{C}$ in a $5 \% \mathrm{CO}_{2}$ incubator and in the presence of $1 \mu \mathrm{g} / \mathrm{ml}$ of concanavalin A (Sigma-Aldrich) for SC and PLNC, and $5 \mathrm{ng} / \mathrm{ml}$ of lipopolysaccharide for PC.

\section{Isolation of pancreatic-infiltrating mononuclear cells}

To obtain pancreatic-infiltrating mononuclear cells, pancreas samples were processed from individual mice by collagenase type $\mathrm{V}$ digestion ${ }^{(17)}$, and digests were passed through a $20 \mu \mathrm{m}$ cell strainer, centrifuged on Histopaque ${ }^{\circledR}-1077$ gradient (Sigma-Aldrich) at $800 \mathrm{~g}$ for $20 \mathrm{~min}$. After centrifugation, mononuclear cells were found between Ficoll and medium, collected, washed and used for flow cytometric analysis.

\section{Immunofluorescence analysis}

The phenotype of PC, SC, PLNC and pancreatic-infiltrating mononuclear cells was assessed by flow cytometry using the following antibodies: rat anti-mouse IgG2bк CD3-PE, CD4PE, IgG2bк CD4-FITC, IgG2aк CD8-PE, IgG1 CD25-PE, IgG2ак F4/80-FITC; Armenian hamster anti-mouse IgM CD40 APC (eBioscience); goat anti-mouse IgG CD206-PE (R\&D). $\mathrm{T}_{\text {reg }}$ were detected by the Mouse Regulatory $\mathrm{T}$ cell Staining Kit, according to the manufacturer's instructions (eBioscience). For intracellular cytokine staining, cells were stimulated with phorbol myristate acetate $(100 \mathrm{ng} / \mathrm{ml})$ and ionomycin $(400 \mathrm{ng} / \mathrm{ml})$ in the presence of Brefeldin A $(5 \mu \mathrm{m})$ (eBioscience) for $4 \mathrm{~h}$. Cells were fixed in $2 \%$ paraformaldehyde, permeabilised and stained for intracellular cytokines with the following antibodies: rat anti-mouse

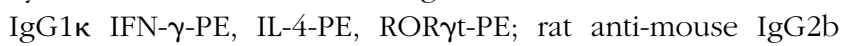
GATA3-APC (eBioscience); IgG1к IL-17-PE (BD Biosciences). Isotype-matched controls were included in all experiments (eBioscience). Stained cells were detected on Partec CyFlow Space and analysed by FlowMax software (Partec).

\section{Determination of cytokine and nitrite levels}

Cytokine concentration in cell-culture supernatants was determined by sandwich ELISA using MaxiSorp plates (Nunck) and anti-mouse paired antibodies, according to the manufacturer's instructions. Samples were analysed in duplicate for murine IL-17, IL-1 $\beta$, TNF (BD Biosciences), IL-10, IL-2 (eBioscience), IFN- $\boldsymbol{\gamma}$ and IL- 4 (R\&D Systems). 
Nitrite accumulation, an indicator of $\mathrm{NO}$ production, was measured in cell-culture supernatants using the Griess reagent $^{(18)}$

\section{Immunoblot analysis}

SC $\left(5 \times 10^{6}\right)$ were disrupted with $500 \mu$ l of TRI Reagent ${ }^{\circledR}$ Solution (Applied Biosystems), mixed with chloroform $(350 \mu \mathrm{l})$ and centrifuged at $12000 \mathrm{~g}$ at $4^{\circ} \mathrm{C}$ for $20 \mathrm{~min}$. The organic phase was used for the isolation of proteins, according to the manufacturer's instruction. The amount of protein was determined by the Lowry method ${ }^{(19)}$. For immunoblot analysis, the following antibodies were employed: rabbit anti-mouse phosphorylated-p38 (1:1000; Cell Signaling Technology); phosphorylated-signal transducer and activator of transcription 3 (STAT3) and STAT3 (1:1000; Santa Cruz Biotechnology); rabbit anti-mouse IgG $\beta$-actin (1:1000; Abcam) followed by incubation with secondary donkey anti-rabbit horseradish peroxidase-linked antibody at 1:10000 dilution (GE Healthcare). Detection was performed by chemiluminescence (ECL; GE Healthcare) and photographs were made by X-ray films (Kodak). Densitometry was performed with Scion Image Alpha 4.0.3.2 (Scion Corporation).

\section{RNA isolation, reverse transcription and $P C R$}

Total RNA was isolated from SC $\left(5 \times 10^{6}\right)$ with TRI Reagent ${ }^{\circledR}$ Solution (Applied Biosystems). RNA $(1 \mu \mathrm{g})$ was reverse transcribed using RevertAid ${ }^{\mathrm{TM}}$ M-MuLV Reverse Transcriptase and random hexamer primers (Fermentas). PCR amplification of complementary DNA was carried out in a real-time PCR machine using the SYBR Green PCR master mix (Applied Biosystems), as described previously ${ }^{(18)}$. Primer pair sequences for $\beta$-actin were $5^{\prime}$-GACCTGACAGACTACC- $3^{\prime}$ and 5'-GGCATAGAGGTCTTTACGG-3' (NM_007393.2), for IL-17 5'-GGAGAGCTTCATCTGT-3' and 5'-GACCCTGAAAGTGAAGGG-3' (NM_010552.3), for RAR-related orphan receptor $\gamma \mathrm{t}$ (ROR $\gamma \mathrm{t}$ ) $5^{\prime}$-CCGCTGAGAGGGCTTCAC-3' and 5'-TGCAGGAGTAGGCCACATTACA-3' (NM_011281.1), and for IL-4 5'-ATCCTGCTCTTCTTTCTCG-3' and 5'-GATGCTCTTTAGGCTTTCC-3' (NM_021283.2). Gene expression was calculated as $2^{-\left(C_{\mathrm{ti}}-C_{\mathrm{ta}}\right)}$ $\left(C_{\mathrm{ti}}\right.$, cycle threshold of the gene of interest; $C_{\mathrm{ta}}, \beta$-actin cycle threshold) and displayed as mean values and standard deviations.

\section{Histology and immunohistochemistry}

Aseptically removed pancreas was fixed in neutral buffered formalin and then embedded in paraffin, sectioned $(5 \mu \mathrm{m}$ thick) and stained with Mayer's haematoxylin (Bio-Optica) to assess the incidence and degree of inflammatory changes. Insulitis scoring was performed by examining at least fifteen islets per mouse and graded in a blinded fashion as follows: grade 0 , intact islet; grade 1, peri-islet infiltrate; grade 2, heavy intra-islet infiltrate. Results are expressed as a percentage of graded islets out of the total number of islets. For immunohistochemical staining, tissues were incubated with $0 \cdot 1 \%$ trypsin for $30 \mathrm{~min}$ at $37^{\circ} \mathrm{C}$ for antigen retrieval, incubated with $3 \% \mathrm{H}_{2} \mathrm{O}_{2}$ for the blockade of endogenous peroxidase and then probed with rabbit anti-nitrotyrosine antibody (1:500; Sigma-Aldrich) or rabbit anti-mouse insulin antibody (1:100; Santa-Cruz Biotechnology) followed by the Rabbit ExtrAvidin Peroxidase Staining Kit (Sigma-Aldrich), according to the manufacturer's instructions. Staining was developed with diaminobenzidine (DakoCytomation), and sections were counterstained with haematoxylin. Representative islets were photographed using a Leica photomicroscope (Leitz) at $\times 400$ magnification.

\section{Culture of murine insulinoma cell lines and primary pancreatic islets}

Rat insulinoma RINm5F cells (ATCC ${ }^{\circledR}$ CRL $\left.11605^{\mathrm{TM}}\right)\left(1 \times 10^{4} /\right.$ well) were cultured in the presence of recombinant mouse or rat cytokines (TNF + IFN- $\gamma+$ IL-1 $\beta$ ) (R\&D Systems), $10 \mathrm{ng} / \mathrm{ml}$ each, with or without MOE $(25-200 \mu \mathrm{g} / \mathrm{ml})$.

Primary pancreatic islets were isolated from C57BL/6 mice. Groups of thirty islets were incubated in the presence or absence of TNF + IFN- $\gamma+$ IL-1 $\beta(10 \mathrm{ng} / \mathrm{ml})$, with or without MOE $(25-100 \mu \mathrm{g} / \mathrm{ml})$.

\section{Caspase 3 assay}

Caspase 3 activity was measured using an assay kit (Biotium), according to the manufacturer's instructions, and quantified fluorometrically (excitation at $485 \mathrm{~nm}$ and emission at $535 \mathrm{~nm}$ ) on a Chameleon plate reader (Hidex).

\section{Cell viability assays}

DNA-histone complexes present in the cytoplasmic fraction of apoptotic islets were detected using Cell Death Detection ELISA (Roche).

Mitochondrial activity of treated RINm5F or PLNC in the presence or absence of concanavalin A was measured using 3-(4,5-dimethyl-2-thiazolyl)-2,5-diphenyl-2H-tetrazolium bromide (MTT) (Sigma-Aldrich) assay, as described previously $^{(18)}$. Cell viability was expressed as a percentage of the control value (untreated cells) that was arbitrarily set to $100 \%$. The proliferative index for PLNC was calculated as a ratio between absorbance values of concanavalin A-stimulated $v$. unstimulated cells after $48 \mathrm{~h}$ incubation.

\section{Determination of antioxidant enzyme activity}

Thawed pancreas was homogenised and sonicated in $0.25 \mathrm{M}$ sucrose, $1 \mathrm{~mm}$-EDTA and 0.05 M-Tris-HCl buffer $\mathrm{pH} 7 \cdot 4$ (all from Sigma-Aldrich) before centrifugation for $90 \mathrm{~min}$ at $105000 \mathbf{g}$. The supernatant was used to determine enzyme activities using a Shimadzu UV-160 spectrophotometer (Shimadzu Scientific Instruments; Shimadzu Corporation). Blood samples were processed as described previously ${ }^{(20)}$. All antioxidant enzyme activities were determined as described previously ${ }^{(20)}$. Briefly, superoxide dismutase (SOD) activity was determined by the adrenaline method after the removal of $\mathrm{Hb}$. One unit of SOD activity is defined as the amount of 
enzyme necessary to decrease by $50 \%$ the rate of adrenalin auto-oxidation at $\mathrm{pH} 10 \cdot 2$. Catalase activity was determined by the rate of $\mathrm{H}_{2} \mathrm{O}_{2}$ disappearance measured at $230 \mathrm{~nm}$. Glutathione peroxidase (GSHPx) activity was determined by the glutathione-dependent reduction of $t$-butyl hydroperoxide (Fluka). One unit of GSHPx activity is defined as the amount needed to oxidise $1 \mathrm{~nm}-\mathrm{NADPH} / \mathrm{min}$ (Sigma-Aldrich) at $25^{\circ} \mathrm{C}$ and $\mathrm{pH} 7 \cdot 0$. Glutathione reductase activity was determined by the assay based on NADPH oxidation concomitant with GSHPx reduction. One unit of glutathione reductase activity is defined as the oxidation of $1 \mathrm{~nm}-\mathrm{NADPH} / \mathrm{min}$ at $25^{\circ} \mathrm{C}$ and $\mathrm{pH} 7 \cdot 4$. All enzyme activities were expressed as units/mg protein. The amount of proteins was determined by the Lowry method.

\section{Statistical analysis}

Data are presented as means and standard deviations for each experimental protocol. Statistical analysis of differences was made using one-way ANOVA, followed by the StudentNewman-Keuls post hoc test and, finally, Student's $t$ test or Mann-Whitney $U$ test, where appropriate. Comparison of diabetes incidence was made using the $\chi^{2}$ test. Statistica 6.0 (StatSoft, Inc.) software was used. $P<0.05$ was considered to be statistically significant.

\section{Results}

\section{Phytochemical composition of oregano extracts}

The liquid chromotography/diode array detection/electrospray ionisation-MS ${ }^{n}$ analysis of the specific extract led to the separation and identification of the majority of the constituents. Since negative ionisation gave higher sensitivity than positive ionisation, the negative ionisation mode was used for the analysis (see online supplementary Fig. S1).

Table 1. Concentrations of compounds in aqueous oregano extract (AOE) and methanolic oregano extract (MOE, $\mathrm{mg} / \mathrm{g}$ dry extract)

(Mean values and standard deviations)

\begin{tabular}{|c|c|c|c|c|}
\hline \multirow[b]{2}{*}{ Compounds } & \multicolumn{2}{|c|}{ AOE } & \multicolumn{2}{|c|}{ MOE } \\
\hline & Mean & SD & Mean & SD \\
\hline Salvianolic acid $\mathrm{H} / \mathrm{l}\left(R_{\mathrm{t}}=13.1 \mathrm{~min}\right)$ & * & * & $5.9 \dagger$ & 0.4 \\
\hline $\begin{array}{l}\text { Salvianolic acid B (lithospermic acid B) } \\
\qquad\left(R_{\mathrm{t}}=14.4 \mathrm{~min}\right)\end{array}$ & $6 \cdot 4 \dagger$ & 0.2 & & * \\
\hline $\begin{array}{l}\text { Salvianolic acid } \mathrm{B} \text { (lithospermic acid } \mathrm{B}) \\
\qquad\left(R_{\mathrm{t}}=15.1 \mathrm{~min}\right)\end{array}$ & $5.9 \dagger$ & $0 \cdot 1$ & * & * \\
\hline Rosmarinic acid $\ddagger\left(R_{\mathrm{t}}=15.7 \mathrm{~min}\right)$ & $53 \cdot 7$ & 4.6 & $98 \cdot 6$ & $6 \cdot 3$ \\
\hline $\begin{array}{l}\text { Salvianolic acid B (lithospermic } \\
\text { acid B) }\left(R_{\mathrm{t}}=16.0 \mathrm{~min}\right)\end{array}$ & $22.5 \dagger$ & $1 \cdot 0$ & $19 \cdot 4 \dagger$ & $2 \cdot 1$ \\
\hline Salvianolic acid C $\left(R_{\mathrm{t}}=16.9 \mathrm{~min}\right)$ & * & * & $5.2 \dagger$ & 0.6 \\
\hline Methyl salvianolate $\mathrm{H} / \mathrm{l}\left(R_{\mathrm{t}}=17.8 \mathrm{~min}\right)$ & - & - & $5.3 \dagger$ & 0.4 \\
\hline Eriodictyol¥ $\left(R_{\mathrm{t}}=18.8 \mathrm{~min}\right)$ & 2.6 & 0.2 & 3.4 & 0.3 \\
\hline Naringenin $\ddagger\left(R_{\mathrm{t}}=21.1 \mathrm{~min}\right)$ & 0.8 & 0.02 & 1.5 & 0.05 \\
\hline Carvacrolf $\left(R_{\mathrm{t}}=28.6 \mathrm{~min}\right)$ & 9.9 & 0.8 & 4.9 & 0.7 \\
\hline
\end{tabular}

$R_{\mathrm{t}}$, retention time.

* These compounds were found in trace amounts in extracts so it was not possible to quantify them.

†These compounds were measured as rosmarinic acid.

$\ddagger$ Identification was confirmed using commercial standards.
Both MOE and AOE presented a similar profile with rosmarinic acid (caffeic acid dimer) as the main compound. The samples also contained other caffeic acid derivatives, such as caffeic acid trimers (salvianolic acid C) and tetramers (dimers of rosmarinic acid (salvianolic acid B)) identified according to $\mathrm{Lu} \& \mathrm{FOO}^{(21)}$, Nuengchamnong et al. $^{(22)}$ and Zeng et al. ${ }^{(23)}$, comparing both their UV spectra and their fragmentation pattern. For the quantitative analysis of these derivatives, the rosmarinic acid calibration curve was utilised in accordance with Barros et al. ${ }^{(24)}$. Detailed analysis of oregano extract composition is given in online supplementary Results and Table S1.

\section{Quantitative measurements of the main compounds in oregano extracts}

Quantitative analysis was performed by the HPLC method using a diode array detector. Since reference compounds for caffeic acid derivatives were not available, they were quantified as rosmarinic acid (at $330 \mathrm{~nm}$ ). Flavonoids, eriodictyol and naringenin, along with carvacrol, were quantified at $280 \mathrm{~nm}$. The calibration curves were proved to be linear for rosmarinic acid in the range of $5-150 \mathrm{mg} / 1$ with $R^{2} 0.995$, for eriodictyol in the range of $2-20 \mathrm{mg} / \mathrm{l}$ with $R^{2} 0.996$, for naringenin in the range of $2-20 \mathrm{mg} / \mathrm{l}$ with $R^{2} 0.988$ and for carvacrol in the range of $5-100 \mathrm{mg} / 1$ with $R^{2}$ 0.999. In total, in MOE, five caffeic acid derivatives along with rosmarinic acid were quantified, and in AOE, three caffeic acid derivatives along with rosmarinic acid were quantified. The quantitatively dominating compounds in both extracts were rosmarinic acid followed by salvianolic acid B-lithospermic acid B. However, the amount of rosmarinic acid in MOE was 2-fold higher than that in AOE (Table 1).

\section{Total phenolic content and antioxidant activity}

The total phenolic content in MOE was $240 \cdot 0$ (SD 15.3) $\mu \mathrm{g}$ caffeic acid/mg of dry extract (mg/g) and 244.2 (SD 4.9) $\mu \mathrm{g}$ caffeic acid $/ \mathrm{mg}$ of dry extract $(\mathrm{mg} / \mathrm{g})$. Antioxidant activity evaluated by the DPPH radical-scavenging assay was 1.5 -fold lower in MOE than in $\mathrm{AOE}\left(\mathrm{SC}_{50}=38.7\right.$ ( $\left.\mathrm{SD} 1.2\right) \mu \mathrm{g} / \mathrm{ml} v$. $\left.\mathrm{SC}_{50}=26 \cdot 1(\mathrm{SD} 2 \cdot 8) \mu \mathrm{g} / \mathrm{ml}\right)$.

\section{Assessment of oregano extracts for the treatment of multiple low doses of streptozotocin-induced diabetes}

To investigate the effect of oregano extracts on T1D development, MLDS-challenged C57BL/6 mice were prophylactically treated either with MOE or AOE. The absence of hyperglycaemia development was observed only in MOE-treated mice (Fig. 1(a)). However, when MOE was applied after diabetes induction as an 'early therapeutic' treatment, it only transiently protected mice from diabetes propagation. After treatment interruption, all mice developed hyperglycaemia (Fig. 1(b)). Therefore, we focused on MOE 'prophylactic' treatment and found that treated mice had higher serum insulin levels (Fig. 1(c)) and significant number of well-preserved $\beta$-cells as determined by immunohistochemical insulin staining (Fig. 1(d)). Also, MOE-treated mice had a lower percentage 
(a)

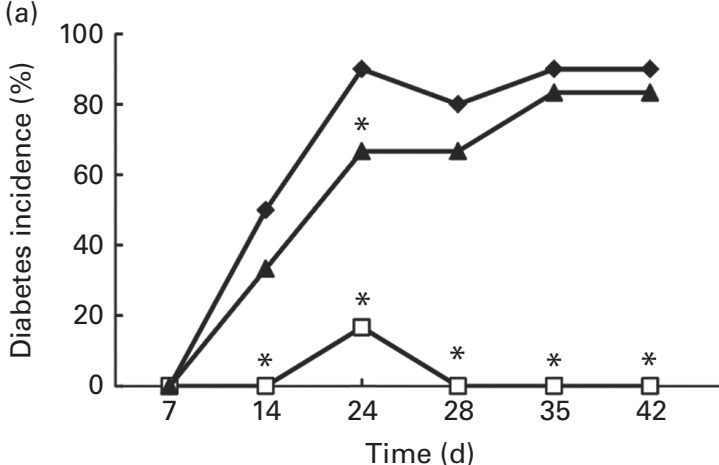

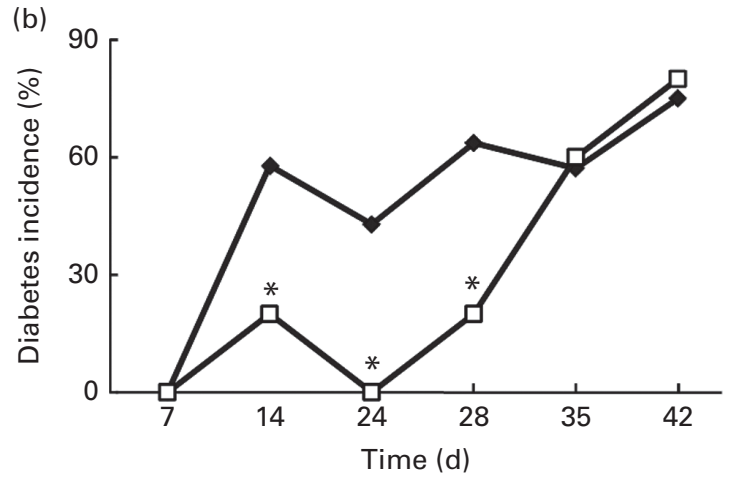

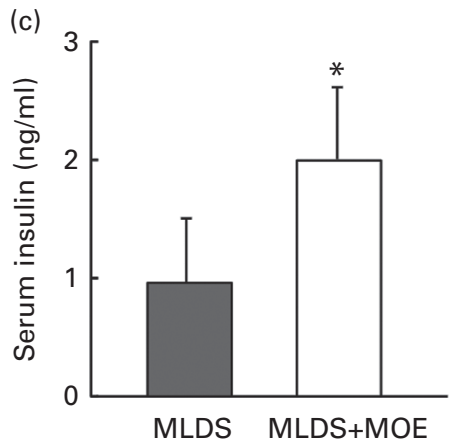

(d)

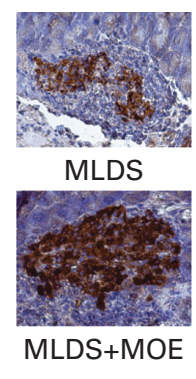

(e)

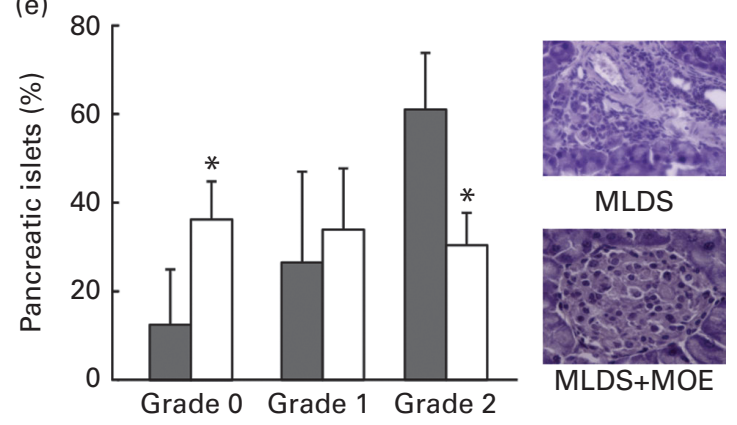

Fig. 1. Methanolic oregano extract (MOE) treatment ameliorates diabetes induction in C57BL/6 mice. (a) C57BL/6 mice were subjected to diabetes induction (multiple low doses of streptozotocin, MLDS) and treated either with MOE (MLDS + MOE) or aqueous oregano extract (AOE; MLDS + AOE) for 10 d (prophylactic treatment). Diabetes incidence was calculated as the percentage of hyperglycaemic animals (blood glucose $\geq 11 \mathrm{mM}$ ). $\neg-, \mathrm{MLDS} ;-\square$, MLDS $+\mathrm{MOE} ; \uparrow$, MLDS + AOE. (b) Diabetes incidence in mice that received MOE under 'early therapeutic' regimen (MOE treatment lasted for 10 d). - -, MLDS; $-\square$, MLDS + MOE therapeutic. (c) Insulin was measured by ELISA $14 \mathrm{~d}$ after the MOE prophylactic treatment (ANOVA followed by the Mann-Whitney $U$ test). (d) Representative pancreatic islet sections stained for insulin. (e) Percentage of pancreatic islets without infiltration (intact): grade 0, mononuclear cells surrounding the islets (periinsulitis); grade 1, mononuclear cell infiltrations (insulitis); grade 2, representative pancreatic islet sections from diabetic (MLDS) and MOE-treated mice (MLDS + MOE). $\square$, MLDS; $\square$, MLDS + MOE. Values are means ( $n 10$ mice per group), with standard deviations represented by vertical bars. ${ }^{*}$ Mean value was significantly different from that of MLDS-treated mice $\left(P<0.05 ; \chi^{2}\right.$ test). A colour version of this figure can be found online at http://www.journals.cambridge.org/bjn.

of islets with mononuclear cell infiltrations (insulitis) compared with diabetic mice, but the same number of islets with benign insulitis (grade 1) (Fig. 1(e)). Importantly, the MOE treatment was well tolerated and had no visible side effects judging by animal behaviour, general appearance and body weight gain (data not shown). In addition, administration of MOE to healthy mice had no impact on their glycaemia, no apparent effect on kidney function (increased concentration of proteins, glucose or erythrocytes in the urine), and the change in leucocyte or erythrocyte concentration in blood was not observed (Table 2). Also, MOE did not alter the activity of glutathione $S$-transferase (a key enzyme involved in the detoxification of xenobiotics in the liver) compared with diluent-treated healthy mice (Table 2).

\section{Antioxidant status of methanolic oregano extract-treated mice}

MLDS application generally results in increased ROS and RNS activities that initially destroy $\beta$-cells of the pancreas ${ }^{(25)}$. Diabetic mice exhibited systemically higher activity of SOD and catalase than mice treated with MOE diluent (DMSO + PBS). MOE itself had no impact on the activity of these enzymes in the blood, while MOE + MLDS-treated mice expressed lower activity of total SOD and catalase, indicating lower levels of superoxide radicals and peroxides, respectively (Fig. 2(a)). However, MLDS-triggered systemic up-regulation of antioxidant defence was not evident within the pancreatic tissue. Interestingly, MOE itself down-regulated GSHPx activity and activated glutathione reductase activity, indicating its antioxidant potential especially at the level of lipid

Table 2. Effect of methanolic oregano extract (MOE) on metabolic parameters in healthy mice

(Mean values and standard deviations, $n 7$ mice per group)

\begin{tabular}{|c|c|c|c|c|}
\hline & \multicolumn{2}{|c|}{$\begin{array}{c}\text { Control + } \\
\text { diluent* }\end{array}$} & \multicolumn{2}{|c|}{$\begin{array}{c}\text { Control + } \\
\text { MOE }\end{array}$} \\
\hline & Mean & SD & Mean & SD \\
\hline Glucose in blood (mmol/l) & $8 \cdot 3$ & 1.4 & $9 \cdot 1$ & 0.5 \\
\hline Proteinuria $(\mathrm{mg} / \mathrm{ml})$ & $0.3 \dagger$ & 0 & 0.3 & 0 \\
\hline Glycosuria & - & - & - & - \\
\hline Erythrocytes in urine & - & - & - & - \\
\hline Leucocytes in blood $\times 10^{9} / \mathrm{ml}$ & $5 \cdot 0$ & 0.9 & $5 \cdot 1$ & 1.2 \\
\hline Erythrocytes in blood $\times 10^{12} / \mathrm{ml}$ & $8 \cdot 7$ & 0.4 & $7 \cdot 9$ & $1 \cdot 1$ \\
\hline GST in liver $\times 10^{2}$ (units/mg protein) & $119 \cdot 0$ & $16 \cdot 1$ & 128.4 & $18 \cdot 3$ \\
\hline
\end{tabular}

GST, glutathione $S$-transferase.

${ }^{*}$ Diluent is PBS + DMSO.

$\dagger$ Normal concentration of proteins in the urine of C57BL/6 mice. 
peroxides and rapid turnover of glutathione (Fig. 2(b)). The percentage of pancreatic islets with nitrosylated proteins, a marker of nitrosative stress, was significantly higher in diabetic than in MOE-treated mice (Fig. 2(c)).

\section{Methanolic oregano extract specifically targets T-cell-mediated immune response}

Although macrophages are the first cells to infiltrate pancreatic islets, MOE did not affect their infiltration, polarisation, cytokine or NO production (see online supplementary Results and Fig. S2). However, MOE successfully suppressed the T-cell-mediated immune response in MLDS-challenged mice judging by lower proliferative capacity of splenocytes (Fig. 3(a)) and the reduced number of activated $\mathrm{CD} 4{ }^{+} \mathrm{CD} 25^{+}$ cells in both peripheral and pancreatic tissues (Fig. 3(b)). Importantly, MOE reduced the number of $\mathrm{T}$ lymphocytes $\left(\mathrm{CD}^{+}\right)$, i.e. it specifically affected the proportion of Th $\left(\mathrm{CD} 4^{+}\right)$cells without an impact on cytotoxic $\mathrm{CD} 8^{+}$lymphocytes within the spleen (Fig. 3(c)), pancreatic lymph nodes (Fig. 3(d)) or pancreatic infiltrates (Fig. 3(e)). Furthermore, the proportion of $\mathrm{T}_{\text {reg }}$ was moderately increased within the spleen (Fig. 3(c)), but significantly enhanced in the pancreatic infiltrates (Fig. 3(e)) after the MOE treatment. Therefore, the immunosuppressive effect of MOE was probably mediated through the reduction in the Th population.

To determine which Th-cell population is affected by MOE, we examined the proportion of Th1, Th17 and Th2 cells by measuring their signature cytokines, IFN- $\gamma$, IL- 17 and IL- 4 , respectively. The results indicated that the suppressive effect of MOE on diabetes development was probably mediated by the inhibition of IL-17 and the up-regulation of IL- 4 production in splenocytes detected both in vitro (Fig. 3(f)) and ex vivo (Fig. 3(g)). The proportion of Th17 cells upon MOE treatment in vivo was reduced in pancreatic lymph nodes (Fig. 3(h)), while their homing to the pancreatic islets was similar as in MLDS-challenged mice (Fig. 3(i)). However, MOE seemed to promote an anti-inflammatory response judging by its significant effect on Th2 cells both at the periphery (Fig. 3(h)) as well as within the pancreas (Fig. 3(i)). Pro-inflammatory Th1 cells and their production of IFN- $\gamma$ remained unaffected by the MOE treatment (Fig. 3(g-i)).

\section{Decoding the mechanism of the methanolic oregano extract-mediated effect on $T$ helper 17, $T$ helper 2 and $T$ regulatory cell differentiation}

To investigate the mechanism of MOE action on Th17 differentiation, we first measured the levels of cytokines that are either involved in the differentiation (IL-6 and transforming growth factor- $\beta$ (TGF- $\beta$ )) or propagation (IL-23) of Th17 cells. Interestingly, MOE increased only the SC-derived production of TGF- $\beta$, without any impact on the other cytokines tested (Table 3). However, it targeted down-stream signalling mediators mandatory for IL-17 expression and production. Namely, the phosphorylation of p38 mitogen-activated protein kinase and the activation of transcription factor STAT3 were significantly reduced (Table 3 ). This probably led to the
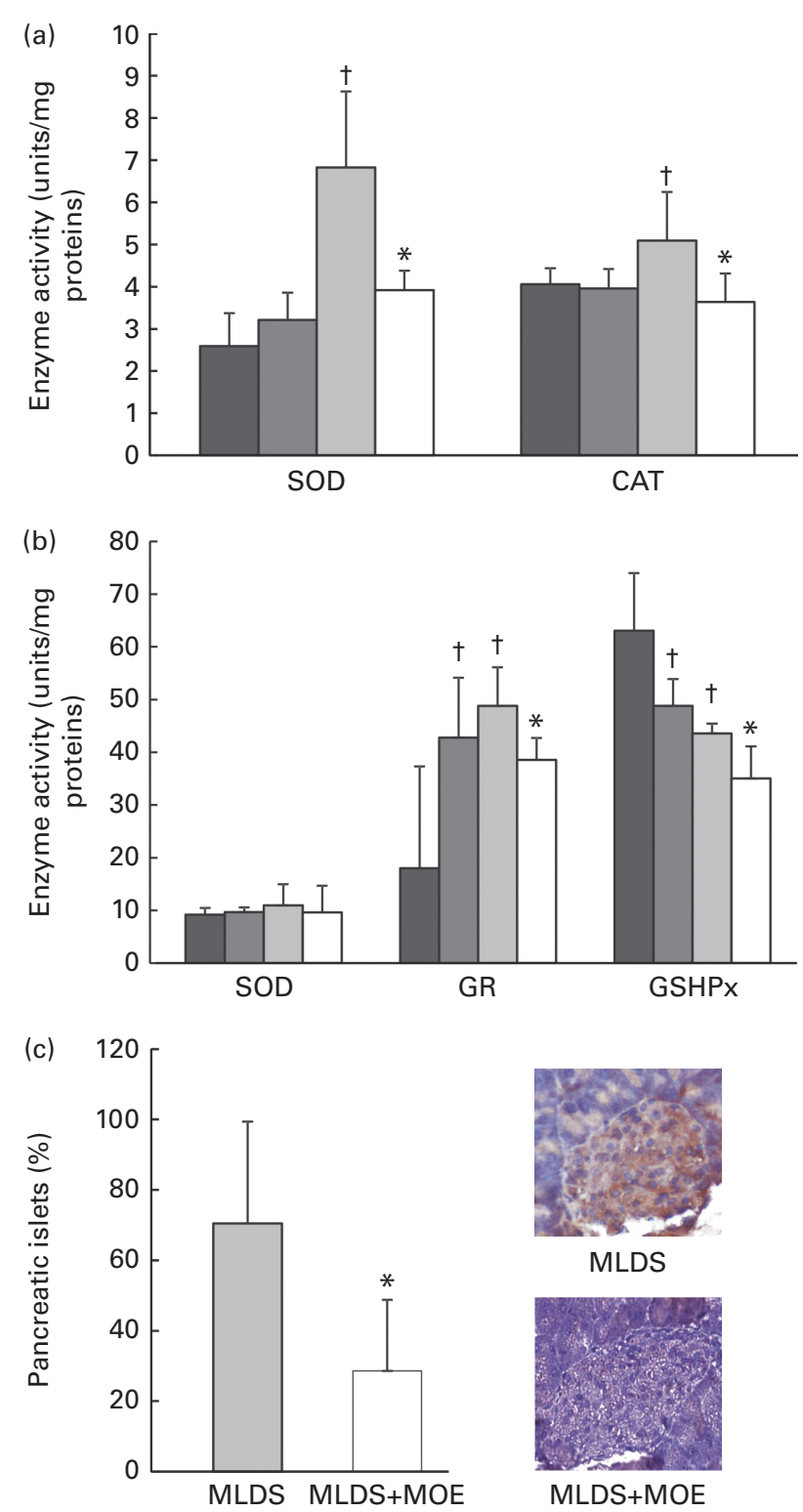

Fig. 2. Effect of methanolic oregano extract (MOE) treatment on the antioxidant status of diabetic mice. (a) Activity of superoxide dismutase (SOD, $\times 1000)$ and catalase $(\mathrm{CAT}, \times 1000)$ within the erythrocytes of C57BL/6 mice receiving $\mathrm{PBS}+\mathrm{DMSO}$ (diluent, control, $\square$ ), MOE-treated control mice (control + MOE, $\square$ ), diabetic mice (multiple low doses of streptozotocin (MLDS), $\square$ ) and MOE-treated mice (MLDS + MOE, $\square$ ) 14d post-diabetes induction. (b) Activities of antioxidant enzymes within the total pancreas homogenate $14 \mathrm{~d}$ post-diabetes induction. (c) Percentage of pancreatic islets stained with anti-nitrotyrosine antibody in MLDS and MLDS + MOE-treated mice. Representative pancreatic islet sections are shown. Values are means (n 7-10 mice per group), with standard deviations represented by vertical bars. * Mean value was significantly different from that of MLDS-treated mice $(P<0.05$; ANOVA followed by the Mann-Whitney $U$ test). $\dagger$ Mean value was significantly different from that of the control group $(P<0.05$; ANOVA followed by the Mann-Whitney $U$ test). GR, glutathione reductase; GSHPx, glutathione peroxidase. A colour version of this figure can be found online at http://www.journals.cambridge.org/bjn.

marked reduction in the number of ROR $\gamma \mathrm{t}$-containing cells (Fig. 5(c)) as well as the down-regulation of $R O R \gamma t$ mRNA expression. All of these events resulted in the down-regulation of mRNA $I L-17$ expression (Table 3 ). 

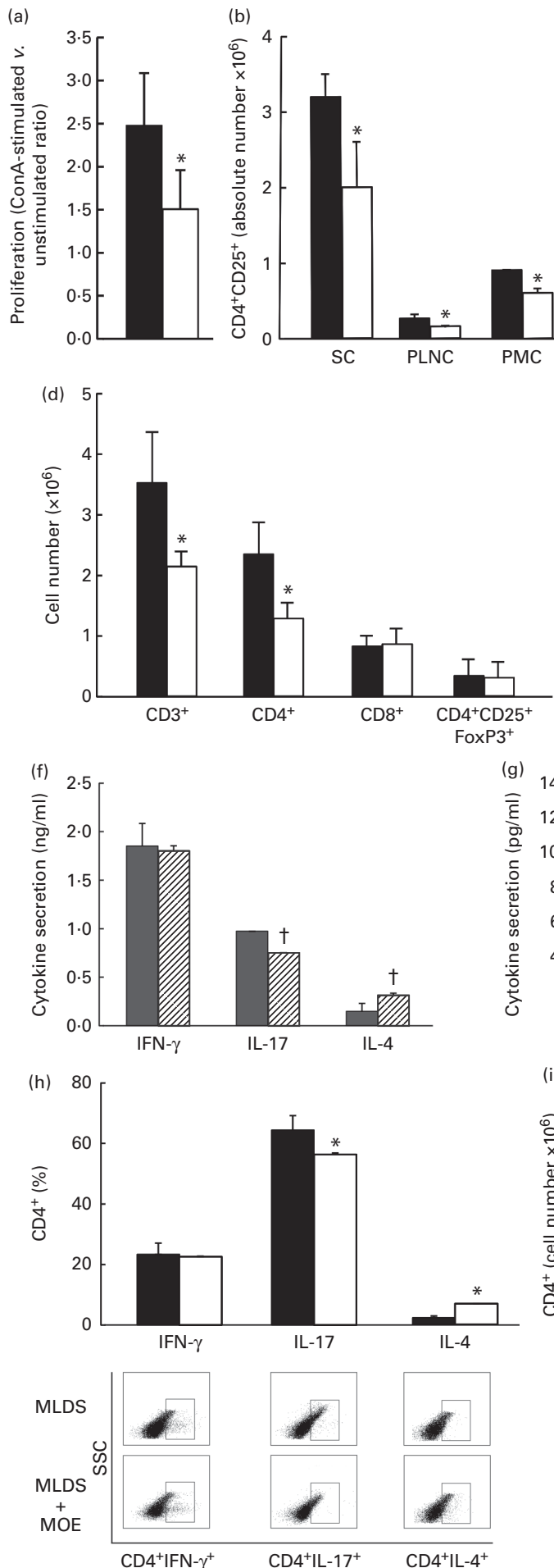
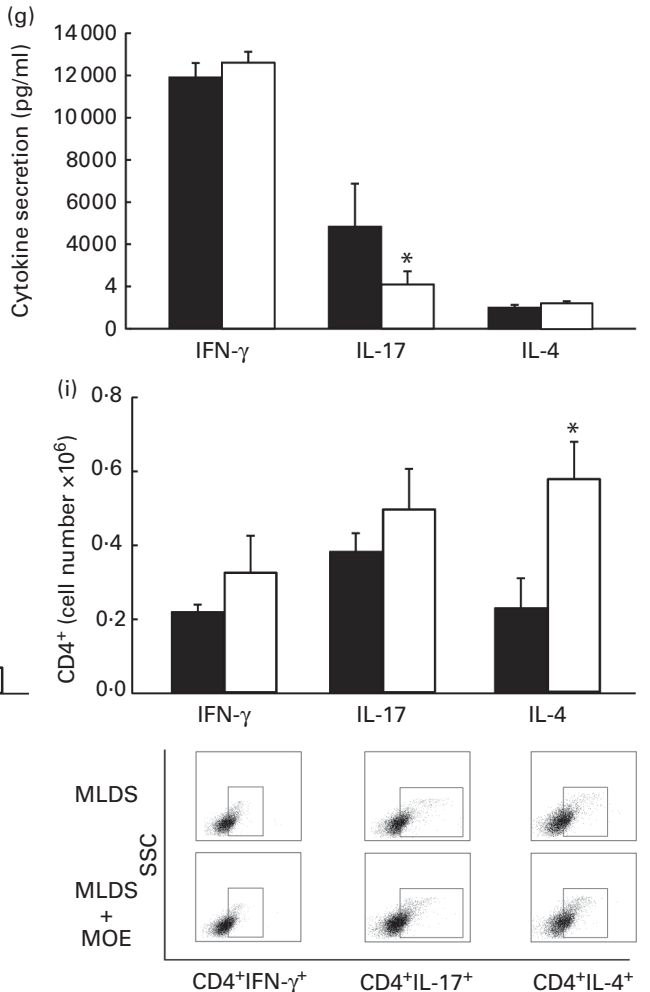

Fig. 3. Effect of methanolic oregano extract (MOE) on lymphocytes. (a) Proliferation of splenocytes isolated from diabetic and MOE-treated mice and cultured with or without concanavalin A (ConA) for $48 \mathrm{~h}$ was determined by the MTT assay. Results are presented as the ratio between ConA-treated cells $v$. untreated cells. (b) Percentage of activated $\mathrm{CD} 4^{+} \mathrm{CD} 25^{+} \mathrm{T}$ lymphocytes within splenocytes (SC), pancreatic lymph node cells (PLNC) and pancreatic mononuclear cell infiltrates (PMC) measured by flow cytometry. Distribution of T lymphocytes within the spleen (c), pancreatic lymph node (d) or pancreatic infiltrates (e) measured by flow cytometry. (f) In vitro cytokine secretion from SC isolated from untreated mice and stimulated with ConA in the presence or absence of MOE (measured by ELISA). (g) ConA-stimulated ex vivo secretion of cytokines from SC isolated from diabetic (multiple low doses of streptozotocin, MLDS) or MOE-treated mice (MLDS + MOE). Distribution of three major subsets of T helper cells within the PLNC (h) or PMC (i) measured by flow cytometry. Representative dot plots are

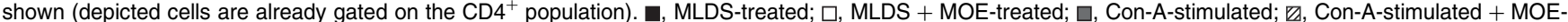
treated. Values are means ( $n 7$ mice per group), with standard deviations represented by vertical bars. * Mean value was significantly different from that of the MLDS-treated mice $(P<0.05$; ANOVA followed by Mann-Whitney $U$ test). $†$ Mean value was significantly different from that of the ConA-treated mice $(P<0.05$; ANOVA followed by Mann-Whitney $U$ test). IFN, interferon; FoxP3, forkhead box P3; SSC, side scatter. 
Table 3. Mechanism of the effect of methanolic oregano extract (MOE) on $T$ helper (Th)17, Th2 and regulatory $T$ cells

(Mean values and standard deviations, $n 5-7$ mice per group)

\begin{tabular}{|c|c|c|c|c|}
\hline & \multicolumn{2}{|c|}{ MLDS } & \multicolumn{2}{|c|}{ MLDS + MOE } \\
\hline & Mean & SD & Mean & SD \\
\hline TGF- $\beta$ secretion† ( $p g / m l)$ & $28 \cdot 8$ & $9 \cdot 3$ & $49 \cdot 4^{\star}$ & $16 \cdot 8$ \\
\hline IL-6 secretiont $(\mathrm{pg} / \mathrm{ml})$ & $217 \cdot 1$ & 88.4 & $161 \cdot 7$ & 21.9 \\
\hline IL-23 secretiont $(\mathrm{pg} / \mathrm{ml})$ & $15 \cdot 6$ & $6 \cdot 7$ & $12 \cdot 2$ & 1.3 \\
\hline pSTAT3/STAT3‡ & $1 \cdot 16$ & 0.04 & $0.62^{*}$ & 0.42 \\
\hline p-p38/p38 & 1.56 & 0.12 & $1.02^{*}$ & 0.22 \\
\hline ROR $\gamma \mathrm{t}^{+}$cells§ (absolute number) & $2 \cdot 20$ & 0.75 & $0.95^{\star}$ & 0.53 \\
\hline Roryt mRNA expression\| & 4.6 & 0.8 & $3 \cdot 6^{*}$ & 0.5 \\
\hline II-17 mRNA expression\| & $12 \cdot 0$ & 4.3 & $4.3^{*}$ & 4.7 \\
\hline II-4 mRNA expression\| & 2.9 & $1 \cdot 1$ & $5 \cdot 3^{\star}$ & 1.3 \\
\hline GATA $-3^{+}$cells $\S$ (absolute number) & 0.29 & 0.22 & $0.69^{*}$ & 0.43 \\
\hline IL-2 secretiont $(\mathrm{pg} / \mathrm{ml})$ & $3167 \cdot 6$ & $1575 \cdot 0$ & $6855 \cdot 9^{\star}$ & $2859 \cdot 0$ \\
\hline FoxP3 $^{+}$cells $\S$ (absolute number) & 0.36 & 0.02 & $0.40^{*}$ & 0.01 \\
\hline
\end{tabular}

MLDS, multiple low doses of streptozotocin; TGF- $\beta$, transforming growth factor- $\beta$; $p$, phosphorylated; STAT3, signal transducer and activator of transcription 3; ROR $\gamma$ t, RAR-related orphan receptor $\gamma \mathrm{t}$; FoxP3, forkhead box P3.

${ }^{*}$ Mean value was significantly different from that of MLDS-treated mice $(P<0.05)$

†Concanavalin A-stimulated secretion of cytokines from spleen cells (SC) was measured by ELISA

$\ddagger$ Protein expression was measured by immunoblot in SC.

§Flow cytometric analysis.

II mRNA expression was measured by real-time PCR in SC.

The up-regulation of Th2 proportion coincided with MOE-mediated increase in $I L-4$ mRNA expression in SC that was probably mediated by the potentiating effect of MOE on GATA binding protein 3 (GATA3) transcription factor (Table 3).

As for the mechanism of $\mathrm{T}_{\text {reg }}$ induction, it was found that MOE enhanced the production of IL-2, a mandatory cytokine for $\mathrm{T}_{\text {reg }}$ development. Also, the mean fluorescence intensity for forkhead box P3 (FoxP3) transcription factor was increased in MOE-treated SC (Table 3).

\section{Methanolic oregano extract protects $\beta$-cells from cytokine insult in vitro}

In addition to its effect on the immune system, MOE exerted a cytoprotective function. In vitro administration of MOE protected RINm5F (rat insulinoma cells) from destructive effect of cytokines (Fig. 4(a)). Also, MOE protected the pancreatic islets isolated from $\mathrm{C} 57 \mathrm{BL} / 6$ mice from apoptosis induction by cytokines in vitro (Fig. 4(b)). The mechanism of the cytoprotective action of MOE was related to the suppression of cytokine-driven caspase 3 activity in the pancreatic islets (Fig. 4(c)).

\section{Effect of rosmarinic acid on diabetes induction in mice}

One of the major differences between the investigated extracts is a 2-fold higher quantity of rosmarinic acid in MOE in comparison with AOE. Therefore, the aim of the present study was to investigate whether rosmarinic acid is the active phytochemical of MOE. In vitro studies have revealed that rosmarinic acid affected both macrophages and lymphocytes. It inhibited macrophage function judging by reduced $\mathrm{NO}$
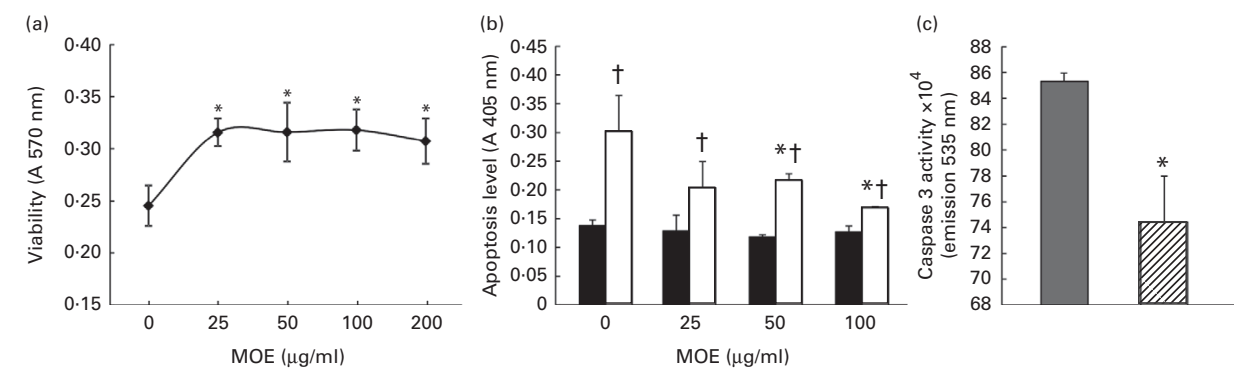

Fig. 4. Methanolic oregano extract (MOE) exerts a cytoprotective effect towards pancreatic $\beta$-cells. (a) Viability of RINm5F cells after $48 \mathrm{~h}$-long treatment with interferon (IFN)- $\gamma+$ TNF + IL-1 $\beta$ alone (point 0) or combination of cytokines and increasing MOE concentrations was measured by the MTT assay. (b) Pancreatic islets were treated with MOE in the absence $(\square)$ or presence of cytokines ( $\square$; IFN- $\gamma$, TNF and IL-1 $\beta$ ) for $24 \mathrm{~h}$ and apoptosis was measured by DNA-Histone ELISA. (c) Caspase 3 activity was measured fluorimetrically after $24 \mathrm{~h}$ of islets incubation with cytokines ( $\square$; IFN- $\gamma$, TNF and IL-1 $\beta$ ) or cytokines in the presence of $50 \mu \mathrm{g} / \mathrm{ml}$ of MOE $(\mathbb{E})$. Values are means, with standard deviations represented by vertical bars. Representative out of three experiments is shown. ${ }^{*}$ Mean value was significantly different from that of the cytokine-only treated group $(P<0.05$; ANOVA followed by Mann-Whitney $U$ test). $\dagger$ Mean value was significantly different from that of the MOE-only-treated group $(P<0.05$; ANOVA followed by Mann-Whitney $U$ test). 
(a)

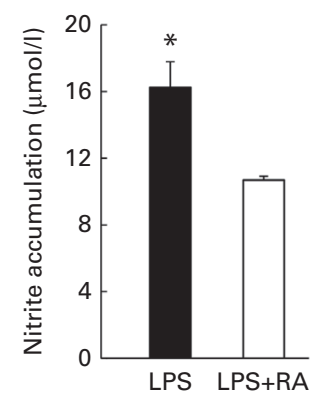

(c)
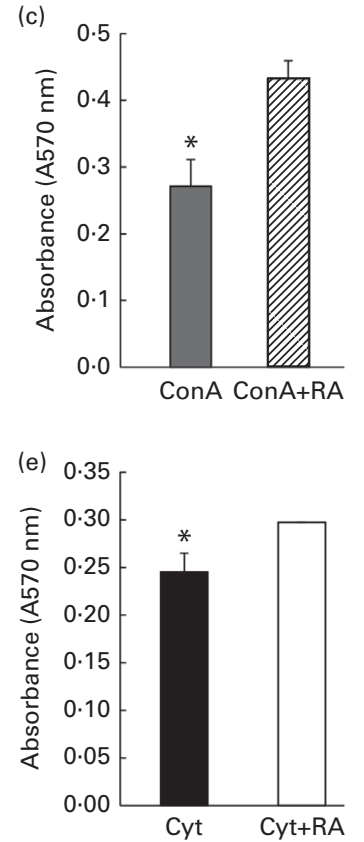

(b)
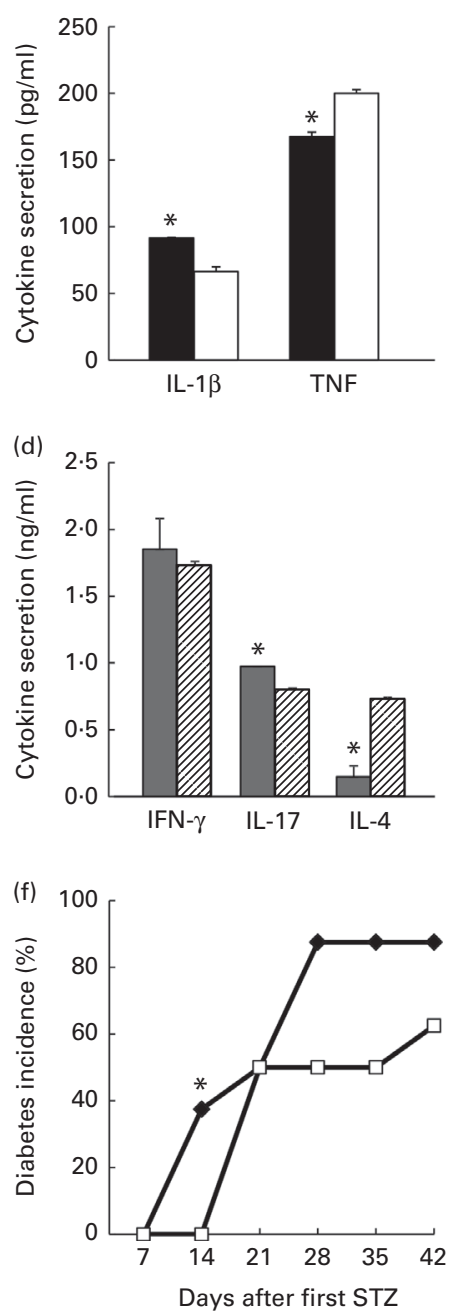

Fig. 5. Rosmarinic acid (RA) only partly protects mice from diabetes induction. Peritoneal cells $\left(1 \times 10^{6} / \mathrm{ml}\right.$ per well) were stimulated in vitro by lipopolysaccharide (LPS) in the presence $(\square)$ or absence $(\square)$ of $50 \mu \mathrm{g} / \mathrm{ml}$ of RA and the secretion of nitric oxide (a) or cytokines (b) was measured after $48 \mathrm{~h}$ of incubation. (c) Spleen cells (SC, $5 \times 10^{6} / \mathrm{ml}$ per well) were stimulated with concanavalin A (ConA) in the presence $(\square)$ or absence ( $\square$ ) of $50 \mu \mathrm{g} / \mathrm{ml}$ of RA and cell proliferation was determined by the MTT assay. (d) In vitro secretion of cytokines from SC stimulated with ConA in the presence ( $(\mathbb{C})$ or absence ( $\square$ ) of $50 \mu \mathrm{g} / \mathrm{ml}$ of RA, measured by ELISA. (e) Viability of RINm5F cells after $48 \mathrm{~h}$-long treatment with cytokines alone interferon (IFN)- $\gamma+$ $\mathrm{TNF}+\mathrm{IL}-1 \beta$ (Cyt) or in combination with $50 \mu \mathrm{g} / \mathrm{ml}$ of RA (Cyt + RA) was measured by the MTT assay. (f) Mice were challenged prophylactically with multiple low doses of streptozotocin (STZ) and were untreated ( $\bullet$ ) or treated with RA (--). Diabetes incidence was calculated as a percentage of animals that developed hyperglycaemia ( $\geq 11 \mathrm{~mm}$ glucose). Representative out of three in vitro experiments is shown. Values are means ( $n 10$ mice per group), with standard deviations represented by vertical bars. ${ }^{*}$ Mean value was significantly different from that of the RA-treated mice $(P<0.05$; ANOVA followed by Mann-Whitney $U$ test).

production (Fig. 5(a)) and IL-1 $\beta$ secretion (Fig. 5(b)). However, rosmarinic acid stimulated $\mathrm{T}$ lymphocyte proliferation (Fig. 5(c)) and Th2 response (Fig. 5(d)). Also, rosmarinic acid protected $\beta$-cells from cytokine-induced apoptosis (Fig. 5(e)). In contrast to MOE that significantly ameliorated MLDS-induced diabetes progression, rosmarinic acid only partially protected mice from diabetes induction (diabetes incidence $50 \%$, four out of eight mice) (Fig. 5(f)).

\section{Discussion}

In the present study, we have shown that the beneficial effect of MOE on the diabetes development in mice is mediated by its innate antioxidant capacity, the ability to suppress T-cellrelated pro-inflammatory immune response and to block $\beta$-cell apoptosis. Since rosmarinic acid alone was not able to ameliorate diabetes completely, it is reasonable to assume that the active component of MOE is not a single compound, yet it could be rosmarinic acid complemented with some other active component(s) of MOE.

T1D develops as a consequence of T-cell-mediated autoimmune attack that is accompanied by macrophages responsible for ROS- and RNS-mediated damage of $\beta$-cells ${ }^{(4,5)}$. Since MOE possesses antioxidant properties, the MLDS model of diabetes that consolidates nitrosative damage of $\beta$-cells and consecutive $\beta$-cell-directed immune response was chosen for the present study ${ }^{(26)}$. This animal model of diabetes does not closely resemble the disease in humans, but covers several aspects of the autoimmune disease ${ }^{(27)}$. STZ specifically enters $\beta$-cells, causing the generation of superoxide radicals, $\mathrm{H}_{2} \mathrm{O}_{2}$ and hydroxyl radicals ${ }^{(25)}$. However, it seems that the increased level of superoxide and peroxides within the pancreas was not the case in our system at least judging by the absence of SOD and GSHPx activation. However, nitrosylated proteins within the islets prove that the oxidative stress has already occurred in MLDS-treated animals. This discrepancy might be attributed to the fact that the activity of antioxidant enzymes was determined within the whole homogenate of the pancreas, not specifically in the islets. However, it is evident that MLDS + MOE-treated animals had lower systemic activity of antioxidant enzymes compared with diabetic ones. It is plausible that MOE neutralised the generation of ROS and RNS and, therefore, alleviated the need for the up-regulation of antioxidant machinery. The strong antioxidant activity of the extract is mainly attributed to its key phenolic compounds such as rosmarinic acid, salvianolic acid B-lithospermic acid B and caffeic acid that exhibit high radical-scavenging capacity ${ }^{(14,28)}$. It has been shown that caffeic acid dynamically and synergistically interacts with ascorbic acid and $\alpha$-tocopherol and amplifies their antioxidant potential and the protection of cells along mitotic phases ${ }^{(29)}$. Also, the down-regulating effect of MOE on GSHPX in the pancreas of both healthy and MLDS-induced mice can be explained by the known efficacy of its constituent salvianolic acid B to inhibit lipid peroxidation, thus resulting in the redundancy of GSHPx. In addition to the effect mediated by STZ itself, elevated glucose levels contribute to the systemic increase in ROS activity ${ }^{(30)}$. Therefore, along with MOE-mediated antioxidant properties, the absence of hyperglycaemia in treated mice could be an additional reason for the lower activity of antioxidant enzymes.

Several reports have described that extracts rich in biophenols can act directly on glucose metabolism to accelerate glucose transfer from the blood into the cells ${ }^{(12)}$. Having in mind that MOE indeed possesses biophenols, its beneficial effect on diabetes development could be related to its plausible glucose-lowering function. However, MOE administration 
to healthy mice did not alter glycaemia, suggesting that MOE does not affect glucose metabolism in mice.

Apart from its antioxidant action, MOE successfully suppresses the pathogenic immune response during diabetes development. The fact that mice treated with MOE after the induction of diabetes maintained normoglycaemia only during the course of treatment suggests that once the immune response towards $\beta$-cells is established, short-term treatment with MOE is not able to revert it. Also, these results suggest that MOE is not able to induce $\beta$-cell regeneration. However, if long-term treatment is applied, this could provide additional aid in reverting T1D symptoms. There are only a few studies considering the effect of oregano extracts or its oil on the immune response. The present results indicate that MOE action is T cell-specific. The absence of the effect on macrophages is somewhat surprising since oregano oils have been shown to primarily affect macrophage pro-inflammatory cytokine production ${ }^{(31)}$. This discrepancy could be attributed to the different preparations of oregano extracts.

The effect of MOE on Th-cell differentiation is probably crucial for the prevention of diabetes development. T1D is associated with infiltration of pro-inflammatory $\mathrm{CD}^{+}{ }^{+} \mathrm{Th}$ cells and cytotoxic $\mathrm{CD}^{+}$lymphocytes ${ }^{(5)}$. We have found that MOE strictly acts on $\mathrm{CD}^{+}{ }^{+}$Th17 cells. Although the function of Th17 is directed towards anti-microbial defence, there are several studies that implicate Th17 in the autoimmune attack during diabetes pathogenesis ${ }^{(6,32,33)}$. Th17 cell differentiation is initiated by $\mathrm{T}$ cell receptor (TCR) stimulation and the action of TGF- $\beta+$ IL-6/IL-21 ${ }^{(34,35)}$. These cytokines stimulate the expression of ROR $\gamma \mathrm{t}$, a transcription factor mandatory for $I L-17$ expression $^{(33)}$. In contrast, IL-23 is a cytokine important for the stabilisation of the Th17 phenotype ${ }^{(36)}$. According to the results of this study, MOE-mediated interference with
Th17 cells is not at the level of their differentiation or propagation, rather it is generated by the down-regulating effect on p38 mitogen-activated protein kinase and STAT3 phosphorylation that results in ROR $\gamma \mathrm{t}$ suppression. Both p38 and STAT3 are redox-dependent molecules, i.e. both are up-regulated in the presence of peroxides ${ }^{(37,38)}$. Therefore, the reason for their lower activation in MOE-treated mice could actually be a ROS and RNS-free environment.

An important notion is that one naive $\mathrm{T}$ lymphocyte could either develop into Th17 or $\mathrm{T}_{\text {reg }}$ depending upon a cytokine milieu ${ }^{(39)}$. Therefore, the observed up-regulation of the $\mathrm{T}_{\text {reg }}$ population could imply that MOE performs a switch from the pro-Th17 signalling pathway towards the pro- $\mathrm{T}_{\text {reg }}$ pathway within the cell. Having in mind the plasticity of Th17 cell, i.e. their ability of re-differentiating into Th1 or Th1/Th17 cells ${ }^{(28)}$, it could be speculated that the lower percentage of Th17 in MOE-treated animals is the result of their transformation. However, the percentage of Th1/Th17 (data not shown) and Th1 cells did not increase after MOE treatment compared with diabetic animals.

The up-regulation of IL-2 ( $\mathrm{a} \mathrm{T}_{\text {reg }}$ growth factor) and TGF- $\beta$ confirms that MOE promotes $\mathrm{T}_{\text {reg }}$ proliferation ${ }^{(40,41)}$. Of note, a high number of islets from MOE-treated mice exhibited periinsulitis, and these mice still maintained normoglycaemia. This could be a consequence of the composition of the infiltrating population in the islets of MOE-treated animals. Although a similar number of Th1 and Th17 cells compared with diabetic mice was found, the presence of higher Th2 and $\mathrm{T}_{\text {reg }}$ numbers in pancreatic islets infiltrates could account for preventing switch from benign to destructive insulitis in MOE-treated mice. Also, MOE directly protects $\beta$-cells by interfering with apoptosis induced by cytokines. The $\beta$-cells succumb to apoptosis either via ROS and RNS production or

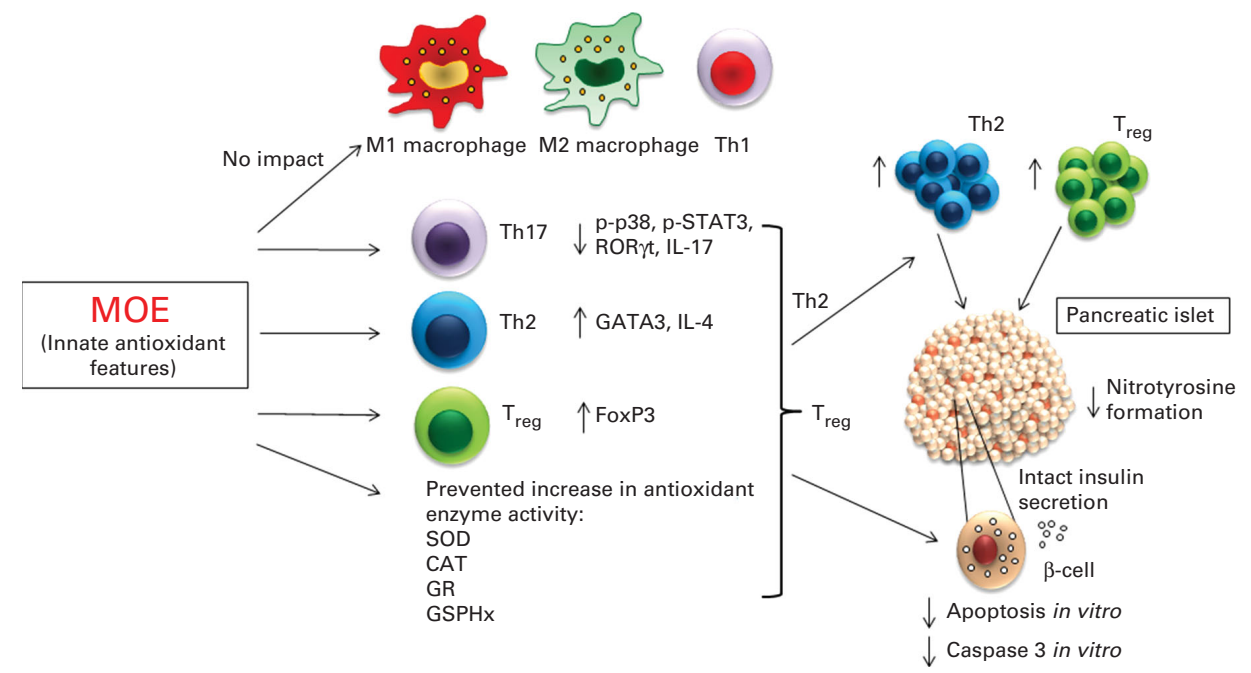

Fig. 6. Mechanism of the anti-diabetogenic action of methanolic oregano extract (MOE). MOE acts as an antioxidant, immunomodulator and in the anti-apoptotic manner. Its innate antioxidant features alleviate the need for the up-regulation of systemic antioxidant machinery (SOD, superoxide dismutase; CAT, catalase; GR, glutathione reductase; GSPHx, glutathione peroxidase). MOE exerts no effect on macrophages and T helper (Th)1 cells (upper left panel), but specifically down-regulates p-p38, phosphor-signal transducer and activator of transcription 3 (p-STAT3) and RAR-related orphan receptor $\gamma \mathrm{t}$ (ROR $\gamma \mathrm{t}$ )-mediated IL-17 production and the number of Th17 cells, up-regulates GATA3-driven IL-4 production and the number of Th2 cells as well as forkhead box P3-mediated regulatory $T$ cells $\left(T_{\text {reg }}\right.$ ) (lower left). By increasing the infiltration of Th2 cells and $T_{\text {reg }}$ within the pancreatic islets (upper right), MOE exerts anti-inflammatory action and preserves normal $\beta$-cell function (insulin secretion). Also, MOE blocks protein nytrosilation and displays cytoprotective properties through the inhibition of caspase 3-driven apoptosis (in vitro data; lower right). A colour version of this figure can be found online at http://www.journals.cambridge.org/bjn 
by cytokine-mediated mitochondrial damage that eventually leads to caspase-induced cleavage of proteins ${ }^{(5,42)}$. The observed cytoprotective effect of MOE could either relate to its innate property for scavenging ROS or to the direct interruption of apoptotic signalling pathways. For several components of MOE has been shown to inhibit apoptosis induction, for example caffeic acid significantly prevented LDL-induced apoptosis in endothelial cells ${ }^{(42)}$, while rosmarinic acid inhibited adriamycin-induced apoptosis cardiac muscle cells ${ }^{(43)}$. Furthermore, salvianolic acid protected PC12 neuronal cells from $\mathrm{H}_{2} \mathrm{O}_{2}$-induced apoptosis by inhibiting caspase 3 activity $^{(44)}$. Similarly, MOE rescued islets from cytokine-driven apoptosis through the down-regulation of caspase 3, an enzyme that cleaves vital cellular proteins at the final stage of the apoptotic process.

Since rosmarinic acid was shown to be beneficial in several inflammatory diseases, and it is a major component of MOE, it was presumed that it could be its active component. Although in vitro results regarding the production of Th signature cytokines and $\beta$-cell cytoprotection are in accordance with the results obtained when using MOE, in vivo treatment was significantly less favourable compared with MOE. Therefore, the presence of other active components could be assumed. Total content of salvianolic acids, for example, is significantly higher in MOE, and this compound proved beneficial in preventing hyperglycaemia induction and oxidative injury in rats ${ }^{(45)}$. Therefore, combination of rosmarinic and salvianolic acids could exert the observed protection from diabetes induction.

MOE is a rich source of biophenols that probably act additively, thus achieving antioxidant, anti-inflammatory and cytoprotective action observed in this model of autoimmune disease (Fig. 6). Future studies should chart the bioactive compound formulation of the extract and investigate a possible translation for human therapy of autoimmune or inflammatory diseases.

\section{Supplementary material}

To view supplementary material for this article, please visit http://dx.doi.org/10.1017/S0007114514004048

\section{Acknowledgements}

The authors are grateful to Karsten Buschard (Bartholin Institutet, Copenhagen, Denmark) for the donation of the RINm5F cells.

The present study was supported by the Ministry of Education, Science and Technological Development, Republic of Serbia (grant no. 173013). It was co-financed by the European Union (European Regional Development Fund) and Greek National Funds Through the Operational Program 'THESSALY-MAINLAND GREECE AND EPIRUS-2007-2013' of the National Strategic Reference Framework (NSRF 2007-2013) and by the European Union (European Social Fund-ESF) and Greek national funds through the Operational Program 'Education and Lifelong Learning' of the National Strategic Reference Framework (NSRF)Research Funding Program: ARISTEIA II, Investing in knowledge society through the European Social Fund.
The authors' contributions were as follows: M. V., S. S.-G., A. G. T. and I. S. designed the research; M. V., I. N., V. G. K., T. S., P. C., Z. O.-D., S. S.-G. and I. S. acquired the data; D. B., A. G. T. and I. S. analysed the data; V. G. K., Z. O.-D. and I. S. drafted the article. All authors revised the manuscript critically and made a final approval of the version to be published.

There are no conflicts of interest to declare.

\section{References}

1. Anderson MS \& Bluestone JA (2005) The NOD mouse: a model of immune dysregulation. Annu Rev Immunol 23, 447-485.

2. van Belle TL, Coppieters KT \& von Herrath MG (2011) Type 1 diabetes: etiology, immunology, and therapeutic strategies. Physiol Rev 91, 79-118.

3. Haskins K, Bradley B, Powers K, et al. (2003) Oxidative stress in type 1 diabetes. Ann N Y Acad Sci 1005, 43-54.

4. Nicolls MR, Haskins K \& Flores SC (2007) Oxidant stress, immune dysregulation, and vascular function in type I diabetes. Antioxid Redox Signal 9, 879-889.

5. Padgett LE, Broniowska KA, Hansen PA, et al. (2013) The role of reactive oxygen species and proinflammatory cytokines in type 1 diabetes pathogenesis. Ann N Y Acad Sci 1281, 16-35.

6. Emamaullee JA, Davis J, Merani S, et al. (2009) Inhibition of Th17 cells regulates autoimmune diabetes in NOD mice. Diabetes 58, 1302-1311.

7. Tang Q, Adams JY, Penaranda C, et al. (2008) Central role of defective interleukin-2 production in the triggering of islet autoimmune destruction. Immunity 28, 687-697.

8. Gallichan WS, Balasa B, Davies JD, et al. (1999) Pancreatic IL-4 expression results in islet-reactive Th2 cells that inhibit diabetogenic lymphocytes in the nonobese diabetic mouse. J Immunol 163, 1696-1703.

9. Del Rio D, Rodriguez-Mateos A, Spencer J, et al. (2013) Dietary (poly)phenolics in human health: structures, bioavailability, and evidence of protective effects against chronic diseases. Antioxid Redox Signal 18, 1818-1892.

10. Yang R \& Shetty K (1998) Stimulation of rosmarinic acid in shoot cultures of oregano (Origanum vulgare) clonal line in response to proline, proline analogue, and proline precursors. J Agric Food Chem 46, 2888-2893.

11. Eddouks M, Maghrani M, Lemhadri A, et al. (2002) Ethnopharmacological survey of medicinal plants used for the treatment of diabetes mellitus, hypertension and cardiac diseases in the south-east region of Morocco (Tafilalet). J Ethnopharmacol 82, 97-103.

12. Lemhadri A, Zeggwagh NA, Maghrani M, et al. (2004) Antihyperglycaemic activity of the aqueous extract of Origanum vulgare growing wild in Tafilalet region. $J$ Ethnopharmacol 92, 251-256.

13. Burt SA \& Reinders RD (2003) Anti-bacterial activity of selected plant essential oils against Escherichia coli O157:H7. Lett Appl Microbiol 36, 162-167.

14. Zhang XL, Guo YS, Wang $\mathrm{CH}$, et al. (2014) Phenolic compounds from Origanum vulgare and their antioxidant and antiviral activities. Food Chem 152, 300-306.

15. Goun E, Cunningham G, Solodnikov S, et al. (2002) Anti-thrombin activity of some constituents from Origanum vulgare. Fitoterapia 73, 692-694.

16. Kontogianni VG, Tomic G, Nikolic I, et al. (2013) Phytochemical profile of Rosmarinus officinalis and Salvia 
officinalis extracts and correlation to their antioxidant and anti-proliferative activity. Food Chem 136, 120-129.

17. Rydgren T \& Sandler S (2002) Efficacy of $1400 \mathrm{~W}$, a novel inhibitor of inducible nitric oxide synthase, in preventing interleukin- $1 \beta$-induced suppression of pancreatic islet function in vitro and multiple low-dose streptozotocin-induced diabetes in vivo. Eur J Endocrinol 147, 543-551.

18. Stojanovic I, Saksida T, Nikolic I, et al. (2012) Macrophage migration inhibitory factor deficiency protects pancreatic islets from cytokine-induced apoptosis in vitro. Clin Exp Immunol 169, 156-163.

19. Lowry OH, Rosenbroudh NJ, Ferr AL, et al. (1951) Protein measurement with Folin phenol reagent. J Biol Chem 193, $265-275$.

20. Nikolic-Kokic A, Stevic Z, Blagojevic D, et al. (2006) Alterations in anti-oxidative defense enzymes in erythrocytes from SALS and FALS patients. Clin Chem Lab Med 44, 589-593.

21. Lu Y \& Foo LY (2002) Polyphenolics of Salvia - a review. Phytochemistry 59, 117-140.

22. Nuengchamnong N, Krittaslip K \& Ingkanina K (2011) Characterization of phenolic antioxidants in aqueous extract of Orthosiphon grandiflorus tea by LC-ESI-MS/MS coupled to DPPH assay. Food Chem 127, 1287-1293.

23. Zeng G, Xiao H, Liu J, et al. (2006) Identification of phenolic constituents in Radix Salvia miltiorrbizae by liquid chromatography/electrospray ionization mass spectrometry. Rapid Commun Mass Spectrom 20, 499-506.

24. Barros L, Dueñas M, Dias MI, et al. (2013) Phenolic profiles of cultivated, in vitro cultured and commercial samples of Melissa officinalis L. infusions. Food Chem 136, 1-8.

25. Szkudelski T (2001) The mechanism of alloxan and streptozotocin action in B cells of the rat pancreas. Physiol Res 50, $537-546$

26. Friesen NT, Büchau AS, Schott-Ohly P, et al. (2004) Generation of hydrogen peroxide and failure of antioxidative responses in pancreatic islets of male $\mathrm{C} 57 \mathrm{BL} / 6$ mice are associated with diabetes induced by multiple low doses of streptozotocin. Diabetologia 47, 676-685.

27. Weide LG \& Lacy PE (1991) Low-dose streptozocin-induced autoimmune diabetes in islet transplantation model. Diabetes 40, 1157-1162.

28. Chen C-Y, Li H, Yuan Y-N, et al. (2013) Antioxidant activity and components of a traditional Chinese medicine formula consisting of Crataegus pinnatifida and Salvia miltiorrhiza. BMC Complement Altern Med 13, 99.

29. Laranjinha J \& Cadenas E (1999) Redox cycles of caffeic acid, $\alpha$-tocopherol, and ascorbate: implications for protection of low-density lipoproteins against oxidation. IUBMB Life $\mathbf{4 8}$, $57-65$.

30. El-Bahr SM (2013) Curcumin regulates gene expression of insulin like growth factor, B-cell CLL/lymphoma 2 and antioxidant enzymes in streptozotocin induced diabetic rats. BMC Complement Altern Med 13, 368-379.

31. Ocaña-Fuentes A, Arranz-Gutiérrez E, Señorans FJ, et al. (2010) Supercritical fluid extraction of oregano (Origanum vulgare) essentials oils: anti-inflammatory properties based on cytokine response on THP-1 macrophages. Food Chem Toxicol 48, 1568-1575.

32. Mensah-Brown EP, Shahin A, Al-Shamisi M, et al. (2006) IL-23 leads to diabetes induction after subdiabetogenic treatment with multiple low doses of streptozotocin. Eur J Immunol 36, 216-223.

33. Korn T, Bettelli E, Oukka M, et al. (2009) IL-17 and Th17 cells. Annu Rev Immunol 27, 485-517.

34. Mangan PR, Harrington LE, O'Quinn DB, et al. (2006) Transforming growth factor- $\beta$ induces development of the $\mathrm{T}(\mathrm{H}) 17$ lineage. Nature 441, 231-234.

35. Zhou L, Ivanov II, Spolski R, et al. (2007) IL-6 programs $\mathrm{T}(\mathrm{H})-17$ cell differentiation by promoting sequential engagement of the IL-21 and IL-23 pathways. Nat Immunol 8 , 967-974.

36. Aggarwal S, Ghilardi N, Xie MH, et al. (2003) Interleukin-23 promotes a distinct $\mathrm{CD} 4 \mathrm{~T}$ cell activation state characterized by the production of interleukin-17. J Biol Chem 278, 1910-1914.

37. Usatyuk PV, Vepa S, Watkins T, et al. (2003) Redox regulation of reactive oxygen species-induced p38 MAP kinase activation and barrier dysfunction in lung microvascular endothelial cells. Antioxid Redox Signal 5, 723-730.

38. Carballo M, Conde M, El Bekay R, et al. (1999) Oxidative stress triggers STAT3 tyrosine phosphorylation and nuclear translocation in human lymphocytes. $J$ Biol Chem 274, $17580-17586$

39. Komatsu N, Okamoto K, Sawa S, et al. (2014) Pathogenic conversion of Foxp3(+) T cells into TH17 cells in autoimmune arthritis. Nat Med 20, 62-68.

40. Chen W, Jin W, Hardegen N, et al. (2003) Conversion of peripheral $\mathrm{CD} 4{ }^{+} \mathrm{CD} 25-$ naive $\mathrm{T}$ cells to $\mathrm{CD} 4{ }^{+} \mathrm{CD} 25^{+}$regulatory $\mathrm{T}$ cells by TGF- $\beta$ induction of transcription factor Foxp3. J Exp Med 198, 1875-1886.

41. Laurence A, Tato CM, Davidson TS, et al. (2007) Interleukin-2 signaling via STAT5 constrains T helper 17 cell generation. Immunity 26, 371-381.

42. Vieira O, Escargueil-Blanc I, Meilhac O, et al. (1998) Effect of dietary phenolic compounds on apoptosis of human cultured endothelia 1 cells induced by oxidized LDL. $\mathrm{Br} J$ Pharmacol 123, 565-573.

43. Kim DS, Kim HR, Woo ER, et al. (2005) Inhibitory effects of rosmarinic acid on adriamycin-induced apoptosis in H9c2 cardiac muscle cells by inhibiting reactive oxygen species and the activations of c-Jun N-terminal kinase and extracellular signal-regulated kinase. Biochem Pharmacol $\mathbf{7 0}$, 1066-1078.

44. Liu CS, Chen NH \& Zhang JT (2007) Protection of PC12 cells from hydrogen peroxide-induced cytotoxicity by salvianolic acid $\mathrm{B}$, a new compound isolated from Radix Salviae miltiorrbizae. Phytomedicine 14, 492-497.

45. Wang SB, Yang XY, Tian S, et al. (2009) Effect of salvianolic acid A on vascular reactivity of streptozotocin-induced diabetic rats. Life Sci $\mathbf{8 5}, 499-504$. 